\title{
Ovine Progressive Pneumonia Virus Is Transmitted More Effectively via Aerosol Nebulization than Oral Administration
}

\author{
Lynn M. Herrmann-Hoesing ${ }^{1 *}$, Stephen N. White ${ }^{1,2,3}$, Liam E. Broughton-Neiswanger ${ }^{1}$, \\ Wendell C. Johnson' ${ }^{2}$, Susan M. Noh ${ }^{1,2}$, David A. Schneider ${ }^{2}$, Hong Li ${ }^{1,2}$, Naomi S. Taus ${ }^{1,2}$, \\ James Reynolds ${ }^{2}$, Thomas Truscott ${ }^{2}$, Rohana P. Dassanayake ${ }^{2}$, Donald P. Knowles ${ }^{1,2}$ \\ ${ }^{1}$ Department of Veterinary Microbiology and Pathology, Washington State University, Pullman, USA \\ ${ }^{2}$ Animal Disease Research Unit, US Department of Agriculture-Agricultural Research Service, \\ Washington State University, Pullman, USA \\ ${ }^{3}$ Center for Integrated Biotechnology, Washington State University, Pullman, USA \\ Email: *1herrman@vetmed.wsu.edu
}

Received June 28, 2012; revised August 1, 2012; accepted August 10, 2012

\begin{abstract}
A new method of experimental infection of ovine progressive pneumonia virus (OPPV), aerosol nebulization ( $\mathrm{Nb}$ ), was compared to intravenous (IV) and oral (PO) methods of experimental infection. Seven month old lambs were given $3.5 \times 10^{7}$ $\mathrm{TCID}_{50}$ of Dubois OPPV LMH19 isolate using IV, PO, or Nb methods and were monitored for infection using cELISA and OPPV quantitative (q) PCR for 35 weeks. Four out of four sheep in the IV group, six out of six sheep in the Nb group, but only two out of six sheep in the PO group became infected by OPPV; whereas the uninoculated controls $(\mathrm{n}=$ 2 ) and a sentinel control $(n=1)$ remained uninfected during the course of the study. The time to a cELISA or OPPV qPCR positive result in the $\mathrm{Nb}$ group was quicker and statistically different from the time to a cELISA or OPPV qPCR positive result in the PO group (cELISA P-value $=0.0021$ and OPPV qPCR P-value $=0.0007$ ). When the $\mathrm{Nb}$ and IV groups were compared, sheep became cELISA and OPPV qPCR positive at similar times (cELISA P-value $=0.6$ and OPPV qPCR P-value $=0.1$ ). In addition, sheep became OPPV qPCR positive prior to cELISA in both the IV and $\mathrm{Nb}$ groups (IV P-value $=0.027$ and $\mathrm{Nb} \mathrm{P}$-value $=0.007$ ). Aerosol nebulization is a more natural experimental method of transmitting OPPV and may be valuable for testing potential vaccines or specific host genetics.
\end{abstract}

Keywords: Ovine Progressive Pneumonia Virus $=$ OPPV; Visna/Maedi Virus $=$ VMV; Small Ruminant Lentivirus $=$ SRLV; Caprine Arthritis-Encephalitis Virus = CAEV; Transmission

\section{Introduction}

The small ruminant lentiviruses (SRLVs) include ovine progressive pneumonia virus (OPPV), visna/maedi virus (VMV) and caprine arthritis-encephalitis virus (CAEV). The SRLVs are part of the family Retroviridae, genus lentivirus that also includes feline immunodeficiency virus, equine infectious anemia virus, bovine immunodeficiency virus, and human immunodeficiency virus. OPPV infection at a minimum results in life-long persistent infection of sheep and may cause clinical signs and histopathological lesions as sheep age. Clinical signs include mastitis, swollen carpal joints, wasting, dypsnea, and ataxia, and histopathological lesions are detected in the congruent tissues such as mammary gland, synovial membranes, lung, and brain. Since clinical signs are variable and histopathological assessment is performed

${ }^{*}$ Corresponding author. post-mortem, antemortem detection of infection is reliant upon highly sensitive and specific serological and molecular diagnostic tests [1-3]. Since there is no known treatment or effective vaccine for SRLVs, annual diagnostic testing followed by removal or separation of infected animals has been the main tool in controlling the number of infected animals.

Many early VMV and OPPV studies suggested that maternal transmission accounted for the majority of natural transmission within a flock. This was primarily based upon the fact that if lambs were removed from their dams prior to suckling and raised artificially and isolated from the flock, the majority of lambs would remain uninfected $[4,5]$. The few lambs that became infected in these scenarios were either thought to have suckled briefly or acquired infection in utero [6]. More recently, field studies in Spanish flocks have shown increased VMV seroprevalence in intensive versus exten- 
sive operations suggesting horizontal transmission plays a large role in transmission [7,8]. Furthermore, a molecular epidemiology study in dam and daughter sets of a naturally infected Idaho, USA ewe flock showed that maternal transmission of OPPV contributed only $10 \%$ $14 \%$ of transmission events; whereas, non-maternal transmission, which includes horizontal transmission and possible paternal transmission during conception, accounted for the remaining $86 \%$ - $90 \%$ of transmission [9]. In the context of the earlier epidemiology studies that relied only on diagnostic testing of serum, isolation of lambs from all infected animals probably contributed more to lowering infection incidence than removal of lambs from their infected mothers.

Identification of the major sources and routes of natural horizontal transmission is of great importance. There have been many studies describing sources of OPPV that could contribute to natural transmission including the bronchial alveolar fluid, colostrum/milk, peripheral blood, and semen. Bronchial alveolar lavage fluid and colostrum/milk contain cell-associated and cell-free virus in SRLV infected animals, which suggests that these sources infect via both horizontal and maternal modes [10-16]. Peripheral blood of SRLV infected animals contains cell-associated virus $[17,18]$ and may be a source of infection for: 1) developing fetuses; and 2) naïve sheep during vaccination needle re-use, tail docking, and shearing. Cell-associated SRLV has been detected in semen of bucks and rams, and cell-free virus has been detected in semen of rams that are co-infected with Brucella ovis $[19,20]$. This suggests that semen may be a source of horizontal sexual transmission and/or paternal transmission.

The site of entry in the naïve animal also needs to be considered for effective SRLV transmission from a source. Currently, the respiratory system is considered the main entry point for SRLV from either respiratory secretions or colostrum/milk of other sheep due to the effectiveness of infection via the experimental intrapulmonary and intratracheal methods [16,21-28]. The intranasal method is considered a less efficient method of experimental infection compared to the intratracheal method since $0.5 \times 10^{7} \mathrm{TCID}_{50}$ was required for intranasal infection whereas $10^{2}$ TCID $_{50}$ was required for intratracheal infection during a titration experiment [28]. In contrast, the intravenous method required only $4 \mathrm{TCID}_{50}$ of OPPV WLC1 to infect lambs making it a very efficient and positive control method of infection; however, it does not represent a natural form of transmission [29]. In addition, maedi-visna virus was shown to be present in the epithelium of the ileum of newborn lambs that had naturally suckled colostrum/milk [30], suggesting that the gastrointestinal tract could be a possible site of entry for virus as well. However, $1 \times 10^{5} \mathrm{TCID}_{50}$ of OPPV infected only 2 out of 10 newborn lambs after oral (PO) administration via bottle feeding, suggesting aspiration and/or ingestion of virus is less effective at causing infection than other experimental infection methods [31]. Although the intravenous, intratracheal and intrapulmonary experimental methods guarantee infection, they are invasive procedures and represent non-natural methods of exposure. Aerosol nebulization $(\mathrm{Nb})$ is not invasive and may represent a more natural experimental method of infection. In this study, we tested aerosol nebulization $(\mathrm{Nb})$ as a new experimental method of infection and hypothesized that aerosol $\mathrm{Nb}$ would infect sheep more effectively than the PO method of infection in terms of the numbers of sheep infected and the rate of cELISA or OPPV qPCR positive results.

\section{Materials and Methods}

\subsection{Animals}

Nineteen Suffolk lambs were derived from an OPPV and ovine herpesvirus 2 free flock. Animals were defined OPPV free based upon multigenerational OPPV diagnostic testing using CAEV cELISA, western blot analysis and OPPV quantitative (q) PCR (see below). Lambs were weaned at 2.5 months and entered the study at seven months of age. The Washington State University Institute for Animal Care and Use Committee approved the animal procedures.

\subsection{Virus Isolation}

A Dubois OPPV LMH19 isolate from colostrum cells [13] was grown and titered in goat synovial membrane (GSM) cells using previously published methods [32]. Briefly, GSM cells were infected with a multiplicity of infection of 0.5 of Dubois OPPV LMH19 for approximately 1.5 weeks in DMEM with $5 \%$ fetal bovine serum. After GSM monolayer obliteration, the supernatant was centrifuged at $1450 \times \mathrm{g}$ for 15 minutes at $4^{\circ} \mathrm{C}$. The resulting supernatant was then centrifuged at $100,000 \times \mathrm{g}$ for 90 minutes at $4^{\circ} \mathrm{C}$. The viral pellet was resuspended with Dulbecco's 1X phosphate buffered saline (PBS), filtered through a 0.22 micron filter, and stored at $4^{\circ} \mathrm{C}$ for 3 weeks until titrations and inoculations were conducted.

\subsection{Infection Methods}

For these studies, a dose of $3.5 \times 10^{7}$ tissue culture infectious doses at $50 \%\left(\mathrm{TCID}_{50}\right)$ of purified Dubois OPPV LMH19 in 1X Dulbecco's PBS was used for inoculations. A $1 \mathrm{ml}$ volume of $3.5 \times 10^{7} \mathrm{TCID}_{50} / \mathrm{ml}$ was given intravenous (IV) into the jugular vein of 4 sheep or was given orally to 6 sheep by placing it under the tongue of the sheep and holding the sheep's muzzle shut for a few seconds. One milliliter of purified Dubois OPPV LMH19 containing $3.5 \times 10^{7} \mathrm{TCID}_{50} / \mathrm{ml}$ in $1 \mathrm{X}$ Dulbecco's PBS 
was diluted with $1 \mathrm{ml}$ of $1 \mathrm{X}$ Dulbecco's PBS and administered to 6 sheep for 6 minutes by aerosol $\mathrm{Nb}$ using a portable nebulizer compressor (Sunrise PulmoAide Compressor/Nebulizer De Vilbiss model \#5650D) and a disposable nebulizer (Sunrise Medical with T-piece, mouthpiece and tubing model \#4650D-621) using previously published methods [33]. The aerosol generated by the compressor flowed from a piece of plastic tubing with an inner diameter of $\sim 1.2 \mathrm{~cm}$ and was placed into the top half of a $2 \mathrm{~L}$ plastic bottle. The large end of the plastic bottle was placed on the muzzle of the sheep, and the plastic tubing was placed in the narrow opening of the 2 L plastic bottle approximately $2.3 \mathrm{~cm}$ away from the sheep's nose and mouth. Nebulization was performed under manual restraint, and a pillowcase was placed over the sheep's head to help calm the animal. Two sheep were used as negative controls where $1 \mathrm{ml}$ of $1 \mathrm{X}$ Dulbecco's PBS was given orally (PO) and $2 \mathrm{ml}$ of $1 \mathrm{X}$ Dulbecco's PBS was given by $\mathrm{Nb}$ to both sheep. One sheep was placed with the negative control group as a sentinel. The negative controls, IV, $\mathrm{Nb}$, and $\mathrm{PO}$ groups were housed in separate isolation rooms or buildings. Siblings were placed in separate groups to ensure maximum genetic diversity within each experimental group.

\subsection{Blood Collection and OPPV Diagnostic Tests}

Sheep were bled by venous jugular puncture into $1-10$ $\mathrm{ml}$ vaccutainer tube without anti-coagulant and $2-10 \mathrm{ml}$ vaccutainer tubes with EDTA (Becton-Dickinson) per time point starting at 3 days prior to infection (prebleed), 1 day post-infection, and every 3 to 4 days for a period ranging from 239 to 246 days. Peripheral blood leukocytes (PBL) were removed from the 2 EDTA vaccutainer tubes following centrifugation at $2000 \times \mathrm{g}$ for 20 minutes at $4^{\circ} \mathrm{C}$. PBL were incubated for 2 minutes with $2 \mathrm{ml}$ of Puregene Red Cell Lysis solution (Qiagen, Inc.), $13 \mathrm{ml}$ of 1X Dulbecco's PBS pH 7.0 with $10 \mathrm{mM}$ EDTA followed by centrifugation at $900 \times \mathrm{g}$ for 10 minutes. Supernatant was removed and residual buffer was used to resuspend the PBL pellet and the pellet was frozen at $-20^{\circ} \mathrm{C}$ until DNA isolation could be performed. Serum was removed from the vaccutainer tube without coagulant after centrifugation at $2000 \times \mathrm{g}$ for 15 minutes at $4^{\circ} \mathrm{C}$ and was stored at $-20^{\circ} \mathrm{C}$ until the cELISA could be performed. DNA was isolated from PBL following manufacturer's directions for 10 million cells using Puregene technology (Qiagen, Inc.). The concentration of DNA was determined using a Nanodrop 2000 spectrophotometer (Thermo Scientific).

A cELISA and a real time OPPV quantitative PCR (qPCR) were utilized to determine OPPV infection status. Serum was tested for OPPV antibodies using a previously validated cELISA [34]. A sheep was considered
cELISA positive if the cELISA measured greater than $20.9 \%$ inhibition on two consecutive time points. Methods for the real time OPPV qPCR have been published [35]. The primers and Taqman probe were designed against a conserved region of envelope that encodes the transmembrane protein. One microgram of DNA from each animal was tested in triplicate within each run in the OPPV qPCR. OPP provirus levels were obtained from the mean OPPV qPCR copy number from the triplicates. OPP levels of greater than 10 copies of envelope $/ \mu \mathrm{g}$ DNA at two consecutive time points were considered OPPV qPCR positive for the presence of OPP provirus. Western blot analysis of sera was performed as previously described using OPPV WLC1 under reduced conditions [36]. Sheep with antibodies to 2 of 3 of the following OPPV proteins: capsid (CA), transmembrane protein (TM), and the surface envelope glycoprotein (SU) were considered OPPV western blot positive. Western blot analyses were performed on pre-infection and 211 days post-infection sera. A sheep was considered OPPV infected if both the cELISA and OPPV qPCR were positive on two consecutive time points and if western blot analysis was positive at 211 days post-infection.

\subsection{Sequencing of OPPV LTR}

DNA from PBL was used to sequence OPPV LTR. Methods for sequencing OPPV LTR have been previously described [9].

\subsection{Statistical Analyses}

Survival curve analyses were used to compare the percentage of remaining cELISA and OPPV qPCR negative sheep over time between and within the various infection method groups. Survival curves were generated and compared using a logrank test and chi-squared analyses using Prism 4.0 c (GraphPad Software Inc.).

\section{Results}

Six sheep were aerosol nebulized with $3.5 \times 10^{7} \mathrm{TCID}_{50}$ of Dubois OPPV LMH19 and all six became OPPV infected based on a positive result by cELISA and OPPV qPCR at two consecutive time points, and a positive western blot result at 211 days post-infection. This Dubois OPPV LMH19 isolate was chosen because it was able to naturally infect horizontally in a previous study [9], and the high dose was chosen to ensure infection in at least one of the different routes. In contrast, only two out of six sheep PO administered with Dubois OPPV LMH19 became OPPV infected as determined by cELISA, OPPV qPCR, and western blot analysis. All four sheep administered Dubois OPPV LMH19 by IV became infected with OPPV as determined by cELISA, OPPV 
qPCR, and western blot analysis. Neither of the two negative controls nor the sentinel sheep became infected with OPPV. To confirm that the sheep were infected by Dubois OPPV LMH19 isolate and not by some other isolate, OPPV LTR was successfully sequenced from PBL of ten infected sheep at 211 days post-infection. Sequence data showed that OPPV LTR was 98.7\% $100 \%$ identical amongst the sheep and the original Dubois OPPV LMH19 provirus indicating that the sheep were infected with Dubois OPPV LMH19 isolate.

Both OPPV qPCR and cELISA were utilized on a daily basis to monitor the sheep infection status of the sheep in the various groups. One first question was which assay, OPPV qPCR or cELISA, first detected OPPV positive sheep within the temporal study. Prior to this study, no one had examined these two specific assays side by side temporally. The $\mathrm{Nb}$ and IV groups were utilized to answer this question since all 6 nebulized sheep and all 4 IV dosed sheep became OPPV infected. Figure 1 shows that the OPPV qPCR was positive prior to the cELISA in both the $\mathrm{Nb}$ and IV groups, and this was statistically significant $(\mathrm{P}$ values $=0.007$ and 0.029 , respectively). The median times to an OPPV qPCR positive result in the $\mathrm{Nb}$ and IV groups were 29.5 and 47 days post infection, respectively, and the median times to a cELISA positive result in the $\mathrm{Nb}$ and $\mathrm{IV}$ groups were 73 and 125.5 days post infection, respectively.

To assess whether $\mathrm{Nb}$ of OPPV produced a cELISA or OPPV qPCR positive test result more quickly than the other methods of infection, the percent negative sheep in the $\mathrm{Nb}$ group over time were compared to the percent negative sheep over time in the IV and PO groups. Figure 1 shows that the $\mathrm{Nb}$ and IV groups do not statistically vary in terms of the percent OPPV qPCR or cELISA negative sheep over time (P-values $=0.1$ and 0.6 , respectively). However, sheep in the $\mathrm{Nb}$ group became

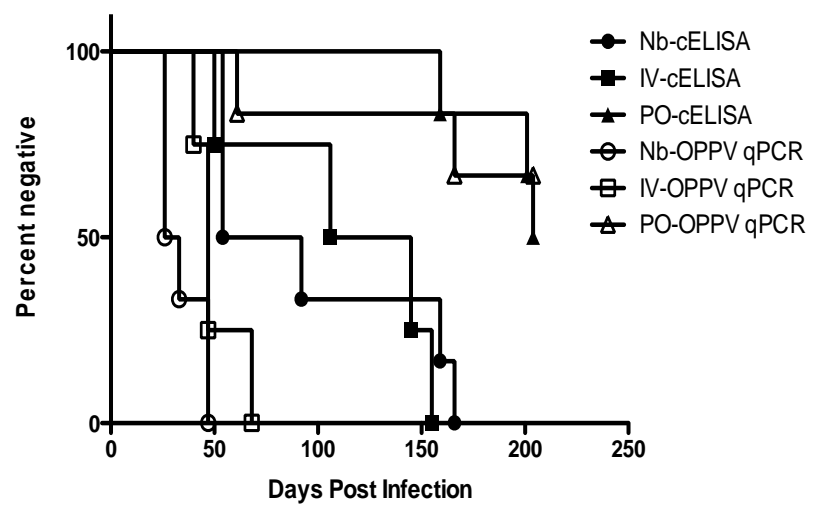

Figure 1. Percent cELISA and OPPV qPCR negative sheep plotted as a function of days post infection for aerosol nebulization (Nb), intravenous (IV) and oral (PO) groups. A positive test is defined as a cELISA or OPPV qPCR positive result at 2 consecutive time points.
OPPV qPCR and cELISA positive more quickly as compared to the $\mathrm{PO}$ administered group $(\mathrm{P}$ values $=$ 0.0007 and 0.0021 , respectively). The median times to an OPPV qPCR positive result in the $\mathrm{Nb}$ and $\mathrm{PO}$ groups were 29.5 and $>204$ days post infection, respectively, and the median times to a cELISA positive result in the $\mathrm{Nb}$ and PO groups were 73 and 204 days post infection, respectively.

\section{Discussion}

$\mathrm{Nb}$ of $3.5 \times 10^{7} \mathrm{TCID}_{50}$ Dubois OPPV LMH19 was shown to infect more seven month-old lambs than the PO method of delivery, and the rate at which the sheep became cELISA and OPPV qPCR positive was faster in the $\mathrm{Nb}$ group versus the $\mathrm{PO}$ group. Therefore, $\mathrm{Nb}$ is a more effective experimental infection method than PO administration of OPPV under these dosing and specific virus conditions. In addition, $\mathrm{Nb}$ of OPPV was equally effective in infecting lambs as IV administration within the $3.5 \times 10^{7} \mathrm{TCID}_{50}$ infectious dose. However, in the future, a dose dilution should be performed to precisely evaluate the IV and $\mathrm{Nb}$ delivery methods. Nontheless, these results indicate that $\mathrm{Nb}$ is a good experimental infection method to evaluate vaccine candidates and genetic markers that associate with OPPV control.

One reason why $\mathrm{Nb}$ is an effective method of OPPV transmission is that sheep are insufflated with aerosolized viral particles for 6 minutes through mostly the nose, depositing viral particles not only in the upper respiratory tract (nasal and pharyngeal mucosa) but also in the lower respiratory tract, including bronchiolar and alveolar epithelium. One study following intranasal installation of VMV commented that virus isolations from nasal mucous samples were less frequent than from peripheral leukocytes [37]. The fact that they successfully isolated virus from nasal mucous samples suggests that virus may be present in nasal epithelia; however there is no evidence in the literature that OPPV or VMV infects cells of the nasal or pharyngeal mucosa. In contrast, the lower lung is known to be a more permissive site for VMV entry in vivo as compared to the trachea [25]. And, besides generally infecting monocytes, macrophages, and dendritic cells $[17,18,38]$, OPPV and VMV replicate and integrate in alveolar macrophages of the lung of naturally infected sheep $[12,15]$. After nebulization, cell free OPPV may be insufflated to the lower respiratory tract and may directly infect alveolar macrophages. Others have shown that lower respiratory tract alveolar epithelial cells are first to be infected with ovine herpesvirus 2 after aerosol nebulization, and this virus is larger in size than OPPV [39]. Evaluation of tissues and fluids from the upper and lower respiratory tracts for both cell free and cell-associated OPPV early after $\mathrm{Nb}$ may help to under- 
stand the cell types involved in initial infection and dissemination.

The Dubois OPPV LMH19 isolate was originally derived from colostrum cells of an OPPV infected and lactating ewe. The finding that a mammary derived virus passaged through GSM cells can transmit experimentally using aerosol $\mathrm{Nb}$, and the fact that horizontal transmission comprises accounts for the majority of natural infection amongst ewes [7-9] suggests that mammary derived viruses may transmit horizontally by aerosols to naïve ewes in a natural lambing situation. Further experimental OPPV infections using aerosol $\mathrm{Nb}$ of colostrum and milk needs to be conducted on naïve post-partum ewes. In addition, a larger molecular epidemiology study may help with elucidating if naïve post-partum ewes are at highest risk to infection during the lambing season.

Our study is the first to show OPPV infection resulting from oral feeding of older or seven month-old lambs. Previous PO experimental CAEV and OPPV infection studies have utilized only neonatal lambs due to the fact that the gastrointestinal tract of neonatal lambs is only permeable to macromolecules such as immunoglobulins and leukocytes for approximately 48 hours post-parturition [40-42]. Bottle-feeding oral infection studies using $2 \times$ $10^{7}$ TCID $_{50}$ of a Florida CAEV isolate resulted in two out of three $(66 \%)$ neonatal kids becoming infected [43], and bottle-feeding of $3.8 \times 10^{6}$ TCID $_{50}$ of CAEV-63 or CAEV-Co resulted in 17 out of $17(100 \%)$ neonatal kids and 15 out of $18(83 \%)$ neonatal kids becoming infected, respectively [44]. Monitoring of VMV 72 hours following natural colostrum suckling of neonatal lambs showed that provirus and viral capsid were detected in ileum epithelial cells [30]. A previous PO experimental OPPV infection study using $10^{5} \mathrm{TCID}_{50}$ of OPPV given to ten newborn lambs resulted in only two sheep (or 20\%) becoming infected over 19 months [31]. In the 7-month old lambs, it is possible but somewhat unlikely that OPPV survives through the four compartment stomach. A more distinct possibility is that virus was aspirated to the upper and lower respiratory tracts after being placed under the tongue. In addition, if there were open wounds or scars in the mouth, the virus could have directly entered the peripheral blood circulation, or alternatively, the virus could have entered the tonsils, submandibular or parotid lymph nodes where it could disseminate through the lymph and eventually the blood. Again, a temporal evaluation of the tissues and cells during early OPPV PO infection could help establish which mucosal site was the site of entry for OPPV in 7-month old sheep.

\section{Conclusion}

In conclusion, $\mathrm{Nb}$ is as effective as IV administration of OPPV in causing infection, and $\mathrm{Nb}$ is more effective than PO administration of OPPV in causing infection under these dosing and viral isolate conditions. This new method of experimental infection provides a less invasive approach as compared to intravenous, intrapulmonary and intratracheal methods, which require sedation in some cases and surgical procedures. Future experiments are planned to examine another Dubois OPPV isolate along with a titration of virus using $\mathrm{Nb}$ to determine the efficiency of the experimental method. This experimental infection method can be utilized to test new OPPV vaccines or host genetic markers of OPPV control.

\section{Acknowledgements}

We thank Nic Durfee for technical assistance. We thank Alisha Ewing, Evan McQuirk, Ashley Trtek, Emma Karel, and Lori Fuller for routine animal care, handling and bleedings. We thank Dr. Steven Parish, Dr. George Barrington and the WSU large animal clinical residents for their assistance in monitoring the health of the sheep. This work is supported by ARS CWA \#5348-32000029-00D.

\section{REFERENCES}

[1] D. De Andres, D. Klein, N. J. Watt, E. Barriatua, S. Torsteinsdottir, B. A. Blacklaws and G. D. Harkiss, "Diagnostic Tests for Small Ruminant Lentiviruses," Vet Microbiol, Vol. 107, No. 1-2, 2005, pp. 49-62. doi:10.1016/j.vetmic.2005.01.012

[2] M. Pepin, C. Vitu, P. Russo, J. F. Mornex and E. Peterhans, "Maedi-Visna Virus Infection in Sheep: A Review," Veterinary Research, Vol. 29, No. 3-4, 1998, pp. 341367.

[3] L. M. Herrmann-Hoesing, "Diagnostic Assays Used to Control Small Ruminant Lentiviruses," Journal of Veterinary Diagnostic Investigation, Vol. 22, No. 6, 2010, pp. 843-855. doi: $10.1177 / 104063871002200602$

[4] G. F. De Boer, C. Terpstra, D. J. Houwers and J. Hendriks, "Studies in Epidemiology of Maedi/Visna in Sheep," Research in Veterinary Science, Vol. 26, No. 2, 1979, pp. 202-208.

[5] D. J. Houwers, C. D. Konig, G. F. De Boer and J. Schaake, "Maedi-Visna Control in Sheep I. Artificial Rearing of Colostrum-Deprived Lambs," Veterinary Microbiology, Vol. 8, No. 2, 1983, pp. 179-185. doi:10.1016/0378-1135(83)90064-0

[6] R. C. Cutlip, H. D. Lehmkuhl and T. A. Jackson, "Intrauterine Transmission of Ovine Progressive Pneumonia Virus," American Journal of Veterinary Research, Vol. 42, No. 10, 1981, pp. 1795-1797.

[7] I. Leginagoikoa, R. A. Juste, J. Barandika, B. Amorena, D. De Andres, L. Lujan, J. Badiola and E. Berriatua, "Extensive Rearing Hinders Maedi-Visna Virus (MVV) Infection in Sheep," Veterinary Research, Vol. 37, No. 6, 2006, pp. 767-778. doi:10.1051/vetres:2006034

[8] I. Leginagoikoa, E. Minguijon, R. A. Juste, J. Barandika, B. Amorena, D. de Andres, J. J. Badiola, L. Lujan and E. 
Berriatua, "Effects of Housing on the Incidence of Visna/Maedi Virus Infection in Sheep Flocks," Research in Veterinary Science, Vol. 88, No. 3, 2010, pp. 415-421. doi:10.1016/j.rvsc.2009.11.006

[9] L. E. Broughton-Neiswanger, S. N. White, D. P. Knowles, M. R. Mousel, G. S. Lewis, D. R. Herndon and L. M. Herrmann-Hoesing, "Non-Maternal Transmission Is the Major Mode of Ovine Lentivirus Transmission in a Ewe Flock: A Molecular Epidemiology Study," Infection, Genetics and Evolution, Vol. 10, No. 7, 2010, pp. 998-1007. doi:10.1016/i.meegid.2010.06.007

[10] D. S. Adams, P. Klevjer-Anderson, J. L. Carlson, T. C. McGuire and J. R. Gorham, "Transmission and Control of Caprine Arthritis-Encephalitis Virus," American Journal of Veterinary Research, Vol. 44, No. 9, 1983, pp. 16701675.

[11] V. Alvarez, J. Arranz, M. Daltabuit-Test, I. Leginagoikoa, R. A. Juste, B. Amorena, D. de Andres, L. Lujan, J. J. Badiola and E. Berriatua, "Relative Contribution of Colostrum from Maedi-Visna Virus (MVV) Infected Ewes to MVV-Seroprevalence in Lambs," Research in Veterinary Science, Vol. 78, No. 3, 2005, pp. 237-243. doi:10.1016/j.rvsc.2004.09.006

[12] S. J. Brodie, L. D. Pearson, M. C. Zink, H. M. Bickle, B. C. Anderson, K. A. Marcom and J. C. DeMartini, "Ovine Lentivirus Expression and Disease, Virus Replication, but Not Entry, Is Restricted to Macrophages of Specific Tissues," American Journal of Pathology, Vol. 146, No. 1, 1995, pp. 250-263.

[13] L. M. Herrmann-Hoesing, G. H. Palmer and D. P. Knowles, "Evidence of Proviral Clearance Following Postpartum Transmission of an Ovine Lentivirus," Virology, Vol. 362, No. 1, 2007, pp. 226-234. doi:10.1016/j.virol.2006.12.021

[14] C. Lerondelle and R. Ouzrout, "Expression of Maedi-Visna Virus in Mammary Secretions of a Seropositive Ewe," Developments in Biological Standardization, Vol. 72, 1990, pp. 223-227.

[15] L. Lujan, I. Begara, D. Collie and N. J. Watt, "Ovine Lentivirus (Maedi-Visna Virus) Protein Expression in Sheep Alveolar Macrophages," Veterinary Pathology, Vol. 31, No. 6, 1994, pp. 695-703. doi: $10.1177 / 030098589403100610$

[16] T. N. McNeilly, A. Baker, J. K. Brown, D. Collie, G. Maclachlan, S. M. Rhind and G. D. Harkiss, "Role of Alveolar Macrophages in Respiratory Transmission of Visna/Maedi Virus," Journal of Virology, Vol. 82, No. 3, 2008, pp. 1526-1536. doi:10.1128/JVI.02148-07

[17] H. E. Gendelman, O. Narayan, S. Kennedy-Stoskopf, P. G. Kennedy, Z. Ghotbi, J. E. Clements, J. Stanley and G. Pezeshkpour, "Tropism of Sheep Lentiviruses for Monocytes: Susceptibility to Infection and Virus Gene Expression Increase during Maturation of Monocytes to Macrophages," Journal of Virology, Vol. 58, No. 1, 1986, pp. 67-74.

[18] M. D. Gorrell, M. R. Brandon, D. Sheffer, R. J. Adams and O. Narayan, "Ovine Lentivirus Is Macrophagetropic and Does Not Replicate Productively in T lymphocytes," Journal of Virology, Vol. 66, No. 5, 1992, pp. 2679-2688.

[19] A. De La Concha-Bermejillo, S. Magnus-Corral, S. J.
Brodie and J. C. De Martini, "Venereal Shedding of Ovine Lentivirus in Infected Rams," American Journal of Veterinary Research, Vol. 57, No. 5, 1996, pp. 684-688.

[20] K. Peterson, J. Brinkhof, D. J. Houwers, B. Colenbrander and B. M. Gadella, "Presence of Pro-Lentiviral DNA in Male Sexual Organs and Ejaculates of Small Ruminants," Theriogenology, Vol. 69, No. 4, 2008, pp. 433-442. doi:10.1016/j.theriogenology.2007.10.013

[21] I. Begara, L. Lujan, D. D. Collie, H. R. Miller and N. J. Watt, "Early Pulmonary Cell Response during Experimental Maedi-Visna Virus Infection," Veterinary Immunology and Immunopathology, Vol. 55, No. 1-3, 1996, pp. 115-126. doi:10.1016/S0165-2427(96)05623-1

[22] J. L. Cadore, F. Guiguen, G. Cordier, R. Loire, M. Lyon, J. Chastang, T. Greenland, I. Court-Fortune, D. Revel and J. F. Mornex, "Early Events in the Experimental Interstitial Lung Disease Induced in Sheep by the Visna-Maedi Virus," Immunology Letters, Vol. 39, No. 1, 1993, pp. 39-43. doi:10.1016/0165-2478(93)90162-U

[23] P. Deng, R. C. Cutlip, H. D. Lehmkuhl and K. A. Brogden, "Ultrastructure and Frequency of Mastitis Caused by Ovine Progressive Pneumonia Virus Infection in Sheep," Veterinary Pathology, Vol. 23, No. 2, 1986, pp. 184-189. doi: $10.1177 / 030098588602300212$

[24] M. Gudnadottir and P. A. Palsson, "Successful Transmission of Visna by Intrapulmonary Inoculation," The Journal of Infectious Diseases, Vol. 115, No. 3, 1965, pp. 217-225. doi:10.1093/infdis/115.3.217

[25] T. N. McNeilly, P. Tennant, L. Lujan, M. Perez and G. D. Harkiss, "Differential Infection Efficiencies of Peripheral Lung and Tracheal Tissues in Sheep Infected with Visna/Maedi Virus via the Respiratory Tract," Journal of General Virology, Vol. 88, No. 2, 2007, pp. 670-679. doi:10.1099/vir.0.82434-0

[26] S. Preziuso, E. Taccini, G. Rossi, G. Renzoni and G. Braca, "Experimental Maedi Visna Virus Infection in Sheep: A Morphological, Immunohistochemical and PCR Study after Three Years of Infection,” European Journal of Histochemisrty, Vol. 47, No. 4, 2003, pp. 373-378.

[27] B. Sigurdsson, P. A. Palsson and A. Tryggvaddottir, "Transmission Experiments with Maedi," The Journal of Infectious Diseases, Vol. 93, No. 2, 1953, pp. 166-175. doi:10.1093/infdis/93.2.166

[28] S. Torsteinsdottir, S. Matthiasdottir, N. Vidarsdottir, V. Svansson and G. Petursson, "Intratracheal Inoculation as an Efficient Route of Experimental Infection with Maedi-Visna Virus," Research in Veterinary Science, Vol. 75, No. 3, 2003, pp. 245-247. doi:10.1016/S0034-5288(03)00098-5

[29] L. M. Herrmann-Hoesing, H. D. Lehmkuhl and R. C. Cutlip, "Minimum Intravenous Infectious Dose of Ovine Progressive Pneumonia Virus (OPPV)," Research in Veterinary Science, Vol. 87, No. 2, 2009, pp. 329-331. doi:10.1016/i.rvsc.2009.01.006

[30] S. Preziuso, G. Renzoni, T. E. Allen, E. Taccini, G. Rossi, J. C. DeMartini and G. Braca, "Colostral Transmission of Maedi Visna Virus: Sites of Viral Entry in Lambs Born from Experimentally Infected Ewes," Veterinary Microbiology, Vol. 104, No. 3-4, 2004, pp. 157-164. 
doi:10.1016/j.vetmic.2004.09.010

[31] I. A. Schipper, A. Misek, L. Ludemann, M. Light and W. Limesand, "Ovine Progressive Pneumonia Infection via the Oral Route," Veterinary Medicine, Small Animal Clinician, Vol. 78, No. 3, 1983, p. 417.

[32] P. Klevjer-Anderson and W. P. Cheevers, "Characterization of the Infection of Caprine Synovial Membrane Cells by the Retrovirus Caprine Arthritis-Encephalitis Virus," Virology, Vol. 110, No. 1, 1981, pp. 113-119. doi:10.1016/0042-6822(81)90012-X

[33] N. S. Taus, D. L. Traul, J. L. Oaks, T. B. Crawford, G. S. Lewis and H. Li, "Experimental Infection of Sheep with Ovine Herpesvirus 2 via Aerosolization of Nasal Secretions," Journal of General Virology, Vol. 86, No. 3, 2005, pp. 575-579. doi:10.1099/vir.0.80707-0

[34] L. M. Herrmann, W. P. Cheevers, K. L. Marshall, T. C. McGuire, M. M. Hutton, G. S. Lewis and D. P. Knowles, "Detection of Serum Antibodies to Ovine Progressive Pneumonia Virus in Sheep by Using a Caprine Arthritis-Encephalitis Virus Competitive-Inhibition EnzymeLinked Immunosorbent Assay," Clinical and Diagnostic Laboratory Immunology, Vol. 10, No. 5, 2003, pp. 862865.

[35] L. M. Herrmann-Hoesing, S. N. White, G. S. Lewis, M. R. Mousel and D. P. Knowles, "Development and Validation of an Ovine Progressive Pneumonia Virus Quantitative PCR," Clinical and Vaccine Immunology, Vol. 14, No. 10, 2007, pp. 1274-1278. doi:10.1128/CVI.00095-07

[36] D. K. Myers-Evert and L. M. Herrmann-Hoesing, "Ovine Progressive Pneumonia Virus Capsid Is B-Cell Immunodominant Using Western Blot Analysis: A Comparison of Sensitivity between Western Blot Analysis and Immunoprecipitation," Journal of Virological Methods, Vol. 137, No. 2, 2006, pp. 339-342. doi:10.1016/j.jviromet.2006.06.025

[37] H. J. Larsen, B. Hyllseth and J. Krogsrud, "Experimental
Maedi Virus Infection in Sheep: Cellular and Humoral Immune Response during Three Years Following Intranasal Inoculation," American Journal of Veterinary Research, Vol. 43, No. 3, 1982, pp. 384-389.

[38] S. Ryan, L. Tiley, I. McConnell and B. Blacklaws, "Infection of Dendritic Cells by the Maedi-Visna Lentivirus," Journal of Virology, Vol. 74, No. 21, 2000, pp. 10096-10103. doi:10.1128/JVI.74.21.10096-10103.2000

[39] N. S. Taus, D. A. Schneider, J. L. Oaks, H. Yan, K. L. Gailbreath, D. K. Knowles and H. Li, "Sheep (Ovis aries) Airway Epithelial Cells Support Ovine Herpesvirus 2 Lytic Replication in vivo," Veterinary Microbiology, Vol. 145, No. 1-2, 2010, pp. 47-53. doi:10.1016/j.vetmic.2010.03.013

[40] S. G. Campbell, M. J. Siegel and B. J. Knowlton, "Sheep Immunoglobulins and Their Transmission to the Neonatal Lamb," New Zealand Veterinary Journal, Vol. 25, No. 12, 1977, pp. 361-365. doi:10.1080/00480169.1977.34458

[41] R. Halliday, "The Transfer of Antibodies from Ewes to Their Lambs," Journal of Immunology, Vol. 95, No. 3, 1965, pp. 510-516.

[42] K. L. Schnorr and L. D. Pearson, "Intestinal Absorption of Maternal Leucocytes by Newborn Lambs," Journal of Reproductive Immunology, Vol. 6, No. 5, 1984, pp. 329337. doi:10.1016/0165-0378(84)90031-7

[43] N. E. East, J. D. Rowe, J. E. Dahlberg, G. H. Theilen and N. C. Pedersen, "Modes of Transmission of Caprine Arthritis-Encephalitis Virus Infection," Small Ruminant Research, Vol. 10, No. 3, 1993, pp. 251-262. doi:10.1016/0921-4488(93)90130-A

[44] W. P. Cheevers, D. P. Knowles, T. C. McGuire, D. R. Cunningham, D. S. Adams and J. R. Gorham, "Chronic Disease in Goats Orally Infected with Two Isolates of the Caprine Arthritis-Encephalitis Lentivirus," Laboratory Investigation, Vol. 58, No. 5, 1988, pp. 510-517. 